\title{
Permanent Marking of Colored Mice Using Dry Ice
}

\author{
Kazuo OHWADA \\ Laboratory Animal Center, Yamagata University School of Medicine, \\ 2-2-2 Iida-nishi, Yamagata-shi, Yamagata 990-23, Japan
}

(Received 16 October 1990/Accepted 26 February 1991)

\begin{abstract}
Freeze marking, using dry ice, was successfully applied to colored mice for permanent, individual, identification. By this method, a $5-8 \mathrm{~mm}$ piece of dry ice is pressed against the skin of mice for 10 seconds. About 3 weeks after this treatment, spots of white hair growing at the site of treatment became recognizable to the naked eye, and allowed permanent identification of individual animals thereafter. The white spots were very clear in colored mice, and greatly facilitated animal identification as compared to conventional marking methods. Treatment of the animals with dry ice for 10 seconds has no discernible effects on the site of the treatment or the general condition of the animals. - KEY WORDS : colored mice, freeze marking, permanent identification
\end{abstract}

Recently, long-term experiments using colored mice have increased, stimulating the need for the development of effective methods for permanent marking of these animals.

Various methods for individual identification of mice have been developed [4], but the relative advantages and disadvantages [3] of these methods are such that they are unsatisfactory for permanent marking of colored mice. Metal ear tags [4], V-shaped cuts in the ear [2], cutting of limb tips $[4,7]$, cutting of the tail end [4], punching of the ear [2], and dye implantation $[1,6,8]$ are common methods of permanent marking. Moreover, a new laboratory animal identification method using an implantable micro-identification device with an encoded number (merchandise name; Microchip) has been announced in one of the latest publications. [Ball, D. J., et al., Abstract, as presented in the 29 th annual Society of Toxicology Proceeding, 1990, Miami Beach, Florida]

Farrell, et al. [5] tested freeze marking in dogs and cats, and found this method to be effective for permanent marking. Their method used pieces of metal prepared in various shapes which are cooled in an ultra-refrigerating apparatus and attached to the skin of the animals. Recognizable white spots that develop in the shape of the metal pieces make individual identification possible. This method, however, has not been applied to small snimals such as rodents.

In this study, designed to develop a simple and effective method for the permanent marking of small laboratory animals, Farrell's method was applied and tested on colored mice. To simplify their method, only dry ice was used instead of complicated freezing instruments, such as ultra-refrigerating apparatus.

Animals : Five-week-old female C57BL/6 NJcl mice purchased from CLEA Japan Inc., were used.

Housing and feeding conditions : Five animals were housed in each cage, matted with sterilized wood chips in an animal room at an ambient temperature of $22+/-1^{\circ} \mathrm{C}$, and a humidity of $55+/-5 \%$. They were given a commercial, solid stock food, and water ad libitum, with an automatic watering apparatus.

Marking : The hair of the marking sites was clipped thoroughly with a scissors, and a piece of dry ice, 5-8 $\mathrm{mm}$ in diameter, held with tweezers or forceps, was applied to the bare skin. 


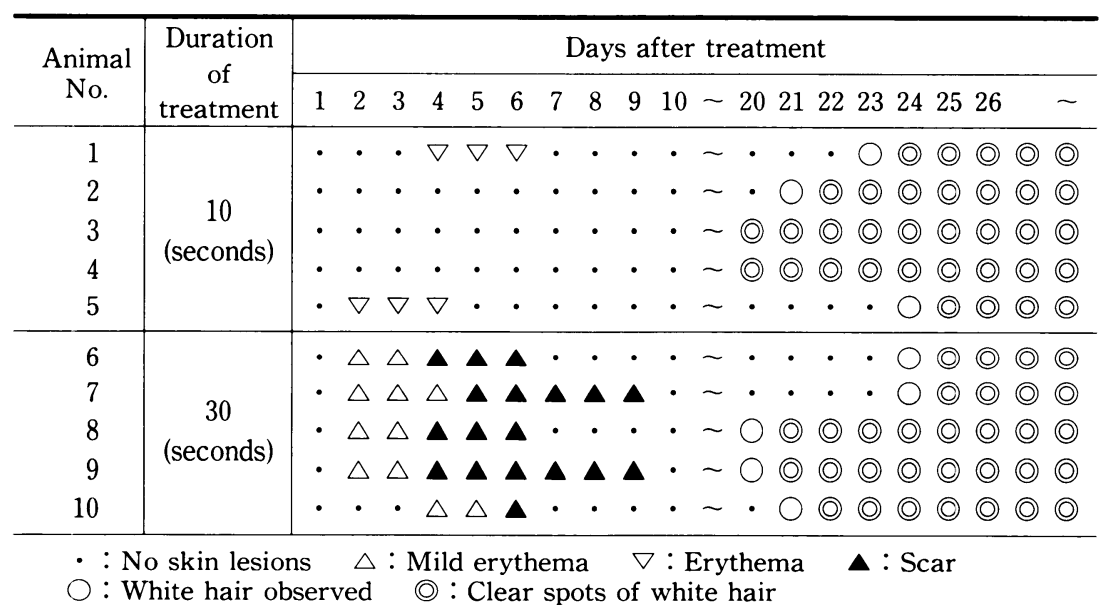

Fig. 1. Skin lesions and hair growth at the marking site after treatment

The dry ice was applied for either 10 or 30 seconds to 5 animals each, under ether anesthesia. In the control group, only the clipping was done.

The marking sites were on the neck to back region, the center of the back, and the origin of the tail, and the animals were identified according to combinations of the three sites.

None of the animals died in either the 10second treatment group or the 30 -second treatment group, and all appeared normal soon after the treatment.

Fig. 1 shows the time course of changes in the 10-second and 30-second treatment groups. Although not shown in the figure, the hair in the shaved areas of the control group grew again, making identification of these animals difficult 14 to 20 days after shaving.

In the dry ice-treated groups, white hair was observed at the treated sites within 20-24 days after treatment. Until the white hair had grown sufficiently to permit identification, shaving at the marking sites served as marks.

As for the effects of the dry-ice treatment, very mild erythema was observed in 2 of the 5 animals in the 10-second treatment group, from 2 to 4 days, and 4 to 6 days after the treatment. However, no ill-effects were thereafter observed in these 2 animals, and no abnormalities were noted in the remaining 3 animals. Fig. 2 shows the photomicrographs of skin treated with dry ice for 10 seconds. Insignificant changes were histologically observed. A gradual decrease of pigmented granular in hair follicles were observed from the third or fourth day of treatment, and they gradually decreased after that.

In the 30-second treatment group, erythema was observed from 2 to 4 days after treatment in all 5 animals, and scars of varying degrees were formed at the marking sites from 6 to 9 days after the treatment.

From these results, permanent marking of colored mice is considered to be possible with minimal hazards to the animals, by the application of dry ice for 10 seconds. Five second and shorter applications did not produce white spots.

White hair developed at the treated sites, also, in the 30 -second treatment group, but a scar was formed at the marking sites a few days after the treatment. Considering the effects of the treatment, the 10-second treatment is judged to be more appropriate.

The method described in this report is very simple, requiring no special instruments such as an ultra-deepfreezer. This method, by which satisfactory markings can be made by a very simple procedure, as compared with Farrell's method, was found to be an excellent method for permanent marking of animals.

Fig. 3 shows a mouse about 12 months after the 10-second dry ice treatment. Spots of white hair are observed in the center of the back (A) and the root of the hail (B).

If animals are not under anesthesia, most conventional methods including tattooing $[1,6$, 
8], ear punching [2], cutting of auricles [2], and cutting of limb tips $[4,7]$, cause pain during the treatment [3]. On the other hand, rapid cooling of the skin has a local anesthetic effect [5], as mentioned by Farrell et al., so that the pain caused by the procedure is considered to be minimal. In addition, little residual effect was observed at the marking site by the $10-$ second treatment.

When colored mice are treated by conventional methods, identification of individual animals tends to become progressively difficult with time or increase in the number of animals. That is, it takes a lot of time to certify an individual animal number, or it becomes difficult to distinguish one from the other. The Microchip system becomes very expensive, and a large-scale setting is essential.

Dry ice freeze marking produces clear white spots, and these remain, even during prolonged experiments, thus avoiding the problems of the conventional methods mentioned above.

From these observations, freeze marking using dry ice is expected to become one of the best identification methods, with simplicity and reliability for permanent identification, not only of colored mice, but of other colored laboratory animals.

\section{References}

[1] Avery, D. L. and Spyker, J. M. (1977). Lab. Anim Sci, 27, 110-111.

[2] Bivin, W. S. and Smith, G. D. (1984). Laboratory Animal Medicine, pp 561-565, Academic Press, Inc., New York.

[3] Cunliffe-Beamer, T. L. and Les, E. P. (1987). The UFAW handbook on the care and management of laboratory animals, pp 275-308, Longman Scientific and Technical, Harlow, Essex.

[4] Dickie, M. M. (1975). Biology of the laboratory mouse, pp 23-27, Dover, New York.

[5] Farrell, R. K. and Johnston, S. D. (1973). Lab. Anim Sci, 23, 107-110.

[6] Greenham, L. W. (1978). Lab. Anim Sci, 28, 346.

[7] Kumar, R. K. (1979). Lab. Anim Sci, 29, 679-680.

[8] Shoenborne, B. M., Schrader, R. E., and Canolty, N. L. (1977). Lab. Anim Sci, 27, 110.

\section{ドライアイスを用いた有色マウスの永久標識法}

$$
\text { 大和田一雄 }
$$

\section{山形大学医学部附属動物実験施設}

有色マウスの永久個体識別法として,ドライアイスを 用いた冷凍標識法を試み, 良好な結果を得た。本法は, 直径5-8 mm のドライアイス片をマウスの皮膚に10秒間 押しあてるだけで, 処置後約 3 週間で処置局所に発育し た白い毛のスポットを肉眼で観察できるようになりここ
れによってそれ以降永久に個体を識別することが可能で ある。有色マウスにおける白色スポットは極めて鮮明で あり, 従来の方法に比べて各個体の識別がはるかに容易 であった。ドライアイス10秒処置では, 動物の処置局所 並びに全身状態に及ぼす影響は認められなかった。

\section{Explanation of Figures}

Fig. 2. Photomicrograph of the skin treated with dry ice for 10 seconds $(\times 100)$ A : Pre-treated B : 4-days after treatment $\mathrm{C}: 10$-days after treatment Insignificant changes were histologically observed. A gradual decrease of pigmented granular in hair follicles were observed from the third or fourth day of treatment, and they gradually decreased after that.
Fig. 3. A mouse marked by the dry ice method Clear spots of white hair are observed in the center of the back (A) and root of the tail (B) about 12 months after the 10 second treatment. Magnified pictures of each white spot, (C) and (D), are shown at the bottom of the figure. 

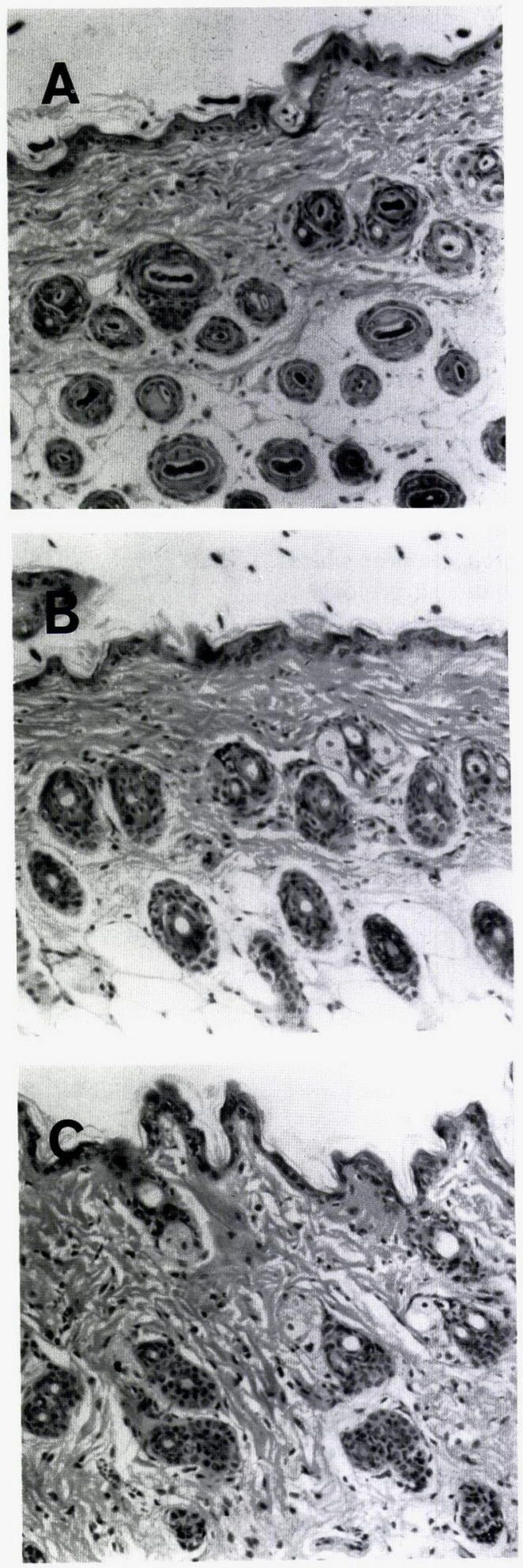

Fig. 2. 



Fig. 3. 